\title{
Legal Implications of the Decision of the Constitutional Court (Cases Number 57, 58, 59 and 63 / PUU-XIV / 2016, Concerning Application for Material Testing of the Republic of Indonesia Number 11 of 2016 Concerning Tax Waivers)
}

\author{
Muhammad Naufal Arifiyanto ${ }^{1}$; I Nyoman Nurjaya ${ }^{2}$; Tunggul Anshari Setia Negara ${ }^{3}$; Bambang \\ Sugiri $^{3}$
}

\author{
Mahasiswa Magister Manajemen, Universitas Mataram, West Nusa Tenggara, Indonesia \\ ${ }^{1}$ Doctoral Law Student, Faculty Law, Universitas Brawijaya, Indonesia \\ ${ }^{2}$ Professor Law, Faculty Law, Universitas Brawijaya, Indonesia \\ ${ }^{3}$ Associate Professor, Faculty Law, Universitas Brawijaya, Indonesia \\ http://dx.doi.org/10.18415/ijmmu.v7i11.2159
}

\begin{abstract}
Law of the Republic of Indonesia Number 11 of 2016 concerning Tax Amnesty is a regulation from the government as part of increasing tax revenue in Indonesia. Tax amnesty is considered to have various deficiencies that injure the value of justice and constitutionality. Review of laws that have been decided by the Constitutional Court with Decisions Number 57, 58, 59 AND 63 / PUU-XIV/2016 and strengthen the a quo law to remain valid in Indonesia. This decision is considered inconsistent with social and legal facts that occur in society. This study intends to answer and analyze how the Constitutional Court's considerations on the examination of the Tax Amnesty Act and to analyze the legal implications after the Constitutional Court decision.
\end{abstract}

Keywords: Tax Amnesty; Constitutional Court Decision

\section{Introduction}

The growth and dynamics of the national economy, especially the taxation sector in recent years have experienced ups and downs with a high tendency to experience a slowdown and decline in the level of state tax revenue, as well as a lack of availability of corporate liquidity (the ability of both domestic and foreing companies located in the territory of Indonesia. To meet the obligation to pay state taxes), especially the level of tax revenue that is needed in the national economy.[1]

The emergence of taxation problems in Indonesia, when some or all of the assets in other countries in the form of personal and corporate assets, capital and investments that are still hidden and have not been reported in the tax returns list, will result in a decrease in the realization of state revenue 
through the system taxation.[2] In order to actualize taxation objectives, a development budget is needed that can increase tax revenues originating from within and outside the country. If in a tax collection system, it can be described as state revenue that is used to improve people's welfare.[3]

If you look at the level of actualization and realization of taxation for a developing country like Indonesia, remembering in the last 5 (five) years that the tax ratio in Indonesia is only in the range of $12 \%$. This number is still very low, when compared to the average tax ratio of neighboring countries such as Malaysia and Singapore, which is in the range above $24 \%$ or another middle income country that is in the range of $16 \%$ to $18 \%$. Not only that, if you use the tax effort indicator (actual tax revenue against its potential), then Indonesia only has a tax effort of 0.47 or tax revenue is still half of its potential.[4]

The portion or share of state revenue in the 2017 APBNP has been allocated in several other elements such as Taxation, Directorate General of Taxes (DGT), Directorate General of Customs and Excise (DJBC), and Oil and Gas Income Tax (PPh Migas) with realization and percentage as of 31 December 2017 as well as the respective quantities.

In 2017 the government received tax revenue that reached 63.2 trillion Rupiah, so that it increased by 470.0 trillion Rupiah with a realization of a percentage of $12.6 \%$ as of 31 December 2017 after the implementation of the Tax Amnesty Law. Then in 2018 the period from January 1 to May 31, 2018 experienced a significant increase with evidence that there is sufficient awareness for every Indonesian citizen to comply and obey tax policies and tax amnesty has been implemented, so that entrepreneurs and people are obliged to pay tax with an additional amount of 68.8 trillion Rupiah in the amount of tax revenue including the implementation of a tax amnesty program with a range of 538.8 trillion Rupiah and with an increase in tax revenue percentage of $14.6 \%$ (plus the application of tax amnesty.

Talking about the problem of tax regulation on the current dynamics of the national economy and it has been explained through previous databases, there are new policies implemented by the government regarding solutions to the national economy, where the economy is experiencing a slowdown which starts from the aspects of the budget balance deficit and the rate of economic growth in the sector. Industry, which has an impact on increasing poverty, unemployment and economic disparities that occur in society, the Indonesian government has issued a policy regarding tax amnesty or tax amnesty.[5]

Based on the description above, the political influence of tax amnesty law has become an interesting legal issue when examined based on statutory regulations (in a regulatory manner), the legal implications of legal policies regarding tax amnesty programs, why the tax amnesty program and since the amnesty legislation. The taxes issued by the government seem hasty, what legal politics are and what legal interests, and political interests, when this program is in effect now.[6] There is legal politics when the enactment of this law, in fact there are several irregularities, including taxpayer compliance issues, tax sanctions, inconsistent legal interpretation issues (especially the laws and regulations above), to the judicial review of this law in the Court Constitution. Therefore, there must be clear normative and empirical formulations, if it achieves targets and targets in each sector, whether it is personal taxpayers, corporate taxpayers, taxpayer sanctions, confidentiality of reporting mechanisms and procedures based on tax data in each taxpayer, as well as fair and transparent regulations at the level of law implementation, and in addition to proper law enforcement for every taxpayer who invests overseas through asset repatriation.[7]

In the end, the placement of appropriate and measured taxes will encourage the reduction of foreign debt of the Indonesian government and support foreign capital market investments that invest their shares in Indonesia, and will increase the country's per capita income in order to create an economy, trade and industry in order to carry out justice and the welfare of the people.[8] 


\section{Research Methodology}

This research is normative legal research. Normative legal research is research that examines legal issues from an in-depth legal perspective on established legal norms.[9]

\section{Research Results and Discussion}

\section{The Politics of Taxation Law on Tax Amnesty Construction in the Positive Dimensions of Indonesian National Law.}

Economic improvement and tax finance obtained from each taxpayer through state cash receipts in the framework of financing development or state infrastructure and superstructure. Basically, the tax function is as a source of state finance and a function to regulate.[10]

Tax amnesty is expected to generate tax revenues that have not been paid or underpaid, in addition to increasing tax compliance due to more effective supervision, supported by more accurate information regarding the list of taxpayers' assets.[11] In other words, this policy is also expected to increase tax subjects and tax objects. The tax subject can be in the form of the return of funds located abroad, while in terms of the tax object it is the addition of the number of taxpayers. Indonesia had implemented a tax amnesty in 1984. However, its implementation was ineffective because taxpayers did not respond to it and it was not followed by a reform of the tax administration system as a whole.

The effectiveness of tax amnesty can be seen when in 1986 it was found that the implementation of tax amnesty in several US states during the previous four years was able to increase taxes significantly. Tax amnesty has even become the main policy in increasing tax revenue in 20 states in the United States.[12]

The policy for granting amnesty as stipulated in Article 14 paragraph (2) of the 1945 Constitution of the Republic of Indonesia is basically the prerogative of the President. In practice, the President grants amnesty and abolition based on the considerations of the House of Representatives. The implications of the amnesty in question are:[13]

1. The highest position or authority is the President to grant amnesty;

2. Legal consequences : loss of wrong doing by the perpetrator of the crime / violation, so that the perpetrator is freed from sanctions or threats in the form of criminal or administrative sanctions;

3. Amnesty must be granted based on law. This is a mandate of the 1945 Constitution of the Republic of Indonesia, which requires the President to receive consideration from the House of Representatives. Amnesty also can only be given at certain moments, not every moment or continuously. This moment is related to political considerations, human rights, the national economy, and the interests of the nation.

\section{Legal Implications of the Constitutional Court Decision on the Material Review of Indonesian}

Although tax amnesty policies come under various names. This then causes moral hazard or psychological anomaly from the taxpayer and makes individuals compare and question perceptions of fairness and equality.[14] In general, tax compliance has increased, but this does not reflect the actual situation.[15] The situation shows that the economic assets originating from money laundering are returned under the legal system. 
This aspect cannot be measured by how to obtain income or assets originating from corruption, money laundering, embezzlement, or the proceeds of crime, in which as a taxpayer must continue to declare and report assets (economic assets).

The results of the analysis of tax amnesty cannot only be obtained from simply knowing tax amnesty as part of government policy, however, in a more comprehensive manner it points to Indonesia's budget economy. The big goal of implementing the tax amnesty policy is expected to increase both the tax subject and the tax object. The tax subject[16] can be in the form of the return of funds that are abroad, while in terms of the tax object it is the addition of the number of taxpayers. Tax amnesty is a method to increase taxpayers by removing administrative and criminal sanctions as part of a tax revenue strategy from tax evaders. When viewed constitutionally, tax amnesty is considered a tool to compromise with criminals, based on Article 20 to Article 23 of the Tax Amnesty Law which states that there is protection of data and information on what is conveyed from taxpayers.[17] This is the basis of the problem that the Tax Amnesty Law becomes the legality of the proceeds from crime. If further examined, data and information on tax amnesty cannot be the basis for criminal investigations, investigations and prosecutions against taxpayers.[18] If later a taxpayer by the competent authority is suspected of being involved in a criminal act, tax amnesty doesn't mean that the state accepts the crime.[19] This is a different domain, predicate offenses will remain attached if later strong evidence is found, that it is true if the source of income is the proceeds of crime, however, the evidence cannot come from tax amnesty data and information. Based on the concept of repatriation, the entry of funds outside Indonesia will add new tax subjects and objects in Indonesia.[20] The current legal fact is that repatriation was only successful in $15 \%$ of the target. Domestic declarations are the main input in the current government era tax amnesty program. This figure is an important note which means that the level of trust of taxpayers who place their assets abroad is still low in the government and the legal system in Indonesia.

\section{Conclusion}

As an effort to increase state revenue, tax amnesty can get legality. However, there are a number of points that need to be underlined. The first is about the legal umbrella. Tax amnesty is an extraordinary policy, so it demands a very strong legal umbrella. Second, forgiveness should not be applied to the elements of a criminal act, but on administrative aspects, such as fines, interest and tax increases. Third, law enforcement against criminal elements should not be neglected for the sake of pursuing state revenue, especially since criminal acts are subject to elements that are detrimental to the state.

The Court in considering legal certainty for judicial review based on the form of regulation, formulation of norms, consistency between norms (vertical and horizontal), and their applicability in a prospective and proportional manner. Considerations in justice and legal benefits are emphasized in the arguments of expert witnesses and the social conditions of the Indonesian people. Tax amnesty has two utility perspectives, in the short term as an addition to state revenue, in which this policy will affect the welfare of society. Then, in the long term as part of the tax reform agenda, which will have an impact on national development.

\section{References}

[1] Alberto F, 2016 Pengaruh Kebijakan Pengampunan Pajak (Tax Amnesty) Oleh Pemerintah Terhadap Potensi Peningkatan Penerimaan Pajak di Indonesia Tahun 2015 J. Ilm. Univ. Bakrie.

[2] Advianto L Y H S, 2018 Pengakuan dan Perlindungan Hukum Hak Hak Wajib Pajak dalam Sistem Hukum Pajak Indonesia Simp. Nas. Keuang. Negara. 
[3] Bram D Al, 2017 Fasilitas Perpajakan (Tax Holiday) Pembebasan Atau Pengurangan Pajak Penghasilan Badan Bagi Perusahaan Industri (Kalangan Dunia Usaha) Yang Melakukan Penanaman Modal Di Indonesia J. Huk. Pembang.

[4] Fenochietto R and Pessino C, 2013 Understanding Countries' Tax Effort IMF Work. Pap.

[5] Puspitasari C D and Ll M, 2012 Puspitasari, C. D., \& Ll, M. (2012). Hukum pajak. Yogyakarta: Universitas Negeri Yogyakarta.Hukum pajak Yogyakarta Univ. Negeri Yogyakarta.

[6] Miraj A, 2019 Hukum Pajak Transf. Pricing di Indones.

[7] Agung I and Kawuryan E S, 2018 Implikasi Akta Nominee Sebagai Dasar Permohonan Pengampunan Pajak Al-Daulah J. Huk. dan Perundangan Islam.

[8] Offe C and Keane J, 2018 Contradictions of the welfare state .

[9] Michael T, 2020 Kesulitan Dalam Memaknai Kesempurnaan Informasi Era Covid-19 Adalah Bul. Huk. dan Keadilan.

[10] Brockmann H Genschel P and Seelkopf L, 2016 Happy taxation: Increasing tax compliance through positive rewards? J. Public Policy.

[11] Hadi, Seno Sudarmono dan R T B, 2018 Pengaruh Pelaksanaan Pengampunan Pajak (Tax Amnesty ) Terhadap Penerimaan Pajak Pada KPP Pratama Jakarta Cengkareng Moneter.

[12] James S and Alley C, 2002 Tax compliance, self-assessment and tax administration J. Financ. Manag. Public Serv.

[13] Darmayasa I N and Aneswari Y R, 2016 The Role Of Local Wisdom to Tax Compliance J. Akunt. Multiparadigma.

[14] Hayat H, 2015 Keadilan Sebagai Prinsip Negara Hukum: Tinjauan Teoritis dalam Konsep Demokrasi PADJADJARAN J. Ilmu Huk. (Journal Law).

[15] Simanungkalit T B, 2017 Analisis Faktor-Faktor Yang Mempengaruhi Kepatuhan Wajib Pajak Pbb P2 Di Kota Tebing Tinggi Provinsi Sumatera Utara J. Ilmu Adm. Media Pengemb. Ilmu dan Prakt. Adm.

[16] onlinepajak.com, 2018, Apa itu Pajak Langsung dan Tidak Langsung?, Apa itu Pajak Langsung dan Tidak Langsung? .

[17] Sa'adah N, 2018 Kebijakan Pengampunan Pajak (Tax Amnesty) Berdasarkan Keadilan Yang Mendukung Iklim Investasi Indonesia Masal. Huk.

[18] , W P, 2016 Penyamaan Persepsi Dan Kerjasama Dalam Pemeriksaan Di Bidang Perpajakan Untuk Mendukung Optimalisasi Penerimaan Negara Yust. J. Huk.

[19] Hidayat S, 2019 Pemidanaan Korporasi Terkait Transfer Pricing Di Bidang Perpajakan Rechtidee.

[20] Sinaga H D P, 2018 The Criminal Liability of Corporate Taxpayer in the Perspective of Tax Law Reform in Indonesia Mimb. Huk. - Fak. Huk. Univ. Gadjah Mada.

\section{Copyrights}

Copyright for this article is retained by the author(s), with first publication rights granted to the journal.

This is an open-access article distributed under the terms and conditions of the Creative Commons Attribution license (http://creativecommons.org/licenses/by/4.0/). 